\title{
William Bartram and Environmentalism
}

\section{Robert Sayre}

In a recent study of Alexander von Humboldt and his influence on nineteenthcentury American environmentalism, Aaron Sachs highlights awareness of the "chain of connection" and a passionate subjective communion with nature as central to the thought and sensibility of the German explorer naturalist. Sachs sees Humboldt as ahead of his time in these respects at the opening of the nineteenth century and suggests that Humboldt may indeed have been "the first ecologist." It could be argued, however, that William Bartram (1739-1823) has an earlier claim to the title. The work usually referred to simply as Bartram's Travels has in recent years become a minor classic in the United States, and its present status, it would seem, is to a large extent due to the rise of modern environmentalism. Since the 1960s, there has been widespread recognition of its author as an eighteenthcentury precursor of the movement that first developed in America via Thoreau, Emerson, and John Muir and came to further fruition in the twentieth century. ${ }^{2}$ At the same time, however, some scholars have questioned the extent to which Bartram was exceptional in relation to his contemporaries and have pointed to contradictions in his work. In this article, I examine the environmental vision of Bartram and its place historically and make the case not only that Bartram's work stands out in its far-reaching protoenvironmentalist thrust but also that this perspective is closely associated with a radical critique of his society, itself unusual in the context of his time. I also argue, against those who have foregrounded Bartram's inconsistencies, that his perspective is remarkably sustained 


\section{Robert Sayre}

and that the inconsistencies, such as they are, do not reside in his fundamental vision.

William Bartram was the son of John Bartram, the renowned Quaker botanist of Philadelphia, who corresponded with and provided specimens for some of the leading lights of European horticulture, botany, and "natural history;" John was named botanist of the king for the North American colonies by George III in 1765. William was an artist and accompanied his father to make sketches on several extensive botanical explorations during his youth. But his Travels, published in Philadelphia in 1791, long after the excursion itself, is the narrative of a much longer journey made alone, between 1773 and 1777, in the Carolinas, Georgia, and East and West Florida, as far west as the lower Mississippi River. ${ }^{3}$ The trip was subsidized by the English horticulturist John Fothergill, also a Quaker, to whom Bartram sent both plant samples and sketches. The areas traversed by Bartram were largely what the British termed "wilderness." Claimed by the latter as part of their North American possessions, they were still inhabited and controlled almost entirely by Native American tribes and nations (though British settlement was making progressive inroads in some regions). Bartram was passionately interested in and attracted to the Indians he encountered and sojourned with, as he was by the wild - though not unmodified - natural environment in which they lived.

Bartram's writings on the trip went through several stages and versions. He first wrote a two-part report - already in the form of a travel narrative - to his patron in England, sent from the South before the expedition had been completed. This report, which has been published, ${ }^{4}$ puts the greatest emphasis on descriptions and enumerations of fauna, flora, and habitats of the kind that its addressee had instructed the traveler to provide. Even in this document aimed at providing "objective" information, however, Bartram gives way in many places to subjective impressions and effusions, evoking his personal responses to the natural world through which he has been traveling. That dimension is much expanded in the travel account written for publication, which Bartram probably began soon after his return to Philadelphia in 1777. Considerable fragments of a first manuscript version of Travels have survived, in which the philosophical and literary elements are paramount. ${ }^{5}$ This early rendering then underwent an editing process (clearly with the aid of persons other than Bartram himself) before the work was finally published, fourteen years after the conclusion of the trip.

The first edition of Travels was generally better received in Europe than in the United States, and in the remaining years of the eighteenth century, the work underwent numerous republications and translations there. The first reviews and the introductions to translations indicate that the book's main interest was initially seen to be scientific, while the literary-philosophical embellishments on the theme of Nature were often criticized. ${ }^{6}$ This very aspect, however, soon came to be treasured by many romantic writers who fell under the spell of Bartram's book: Coleridge, Wordsworth, Carlyle, and Chateaubriand, to name only the most prominent. In addition to these European romantics, however, Travels also came 
to be admired by a number of nineteenth-century American writers of similar sensibilities, most notably by Thoreau and Emerson, often considered the first major figures of American environmental concern and nature writing. Thoreau cites Bartram's work in Walden, and Emerson, to whom Carlyle recommended Travels - though Emerson's journals show that he had already discovered it years earlier-also found inspiration in the book. ${ }^{7}$

Important to understanding Bartram's vision is the specificity of the North American setting. The first colonists found what they saw as "wilderness"lands sparsely populated by peoples whose imprint on them was light—but the "civilizing" of them was rapid at the hands of the newcomers. Annette Kolodny points out that in other parts of the world, "civilisation" of land was an ancient, slow evolution, whereas "only in America has the entire process remained within historical memory, giving Americans the unique ability to see themselves as the wilful exploiters of the very land that once promised an escape from such necessities." ${ }^{8}$ Within that general context, Bartram lived at a time and in a place that were crucial to the process, for the British colonies in the eighteenth century - most markedly in the second half of it - were fast developing into a thoroughly commercial society in which money and market relations were becoming dominant. This early capitalist civilization was still based largely on agriculture, and its expansionist logic called for the continual extension of land possession and development by the colonists. On his trip, Bartram encountered many manifestations of this process.

Other eighteenth-century North American travelers directly participated in it. Among those who crisscrossed the "wilderness" areas were colonizers, settlers moving west, land speculators, and surveyors. Another common type of traveler was the fur trader, engaged in a different kind of commercial exploitation of the land. While the first group was engaged in overall appropriation and transformation of territory, the fur trader left the land intact but nonetheless profoundly marked ecosystems by sharply depleting certain animal populations. Travel accounts by persons engaged in such activities naturally reflected those concerns in their representations of the natural surroundings. In A New Voyage to Carolina (1709), for example, the colonizer and land speculator John Lawson repeatedly comments in the text on the settlement and trade potentialities of areas discovered and notes likely locales on an appended map as well. ${ }^{9}$ At the other end of the century, the important fur trader Alexander Mackenzie's account of his exploratory ventures in search of the Northwest Passage treats the land principally as the source of raw materials or as a conduit for commerce and the Indians he deals with either as potentially helpful agents or as hindrances to his enterprises. ${ }^{10}$ Even travelers not directly involved in the exploitive activities mentioned were often influenced in their narratives by these conceptions of land and by perceived reader expectations.

As for the travelers who were studying "natural history," Roderick Nash notes in his study of American attitudes toward the wilderness that they "occupied a vantage point from which wilderness could be regarded with something other 


\section{Robert Sayre}

than hostility"- the hostility, that is, of the earlier Puritan view of wild nature as the realm of the demonic or that of the settlers who sought to subdue and appropriate it (their "hostility" was utilitarian and often mercenary). Yet up to the middle of the eighteenth century, according to Nash, natural scientists "shared the dominant point of view." Only then was "a new note sounded in descriptive, scientific writing," one more appreciative of the natural world. Even in the later part of the century, though, "[t]he new attitude coexisted with, rather than replaced, the old," and William Bartram's approach stood out as exceptional. ${ }^{11}$ Only in the nineteenth century and beyond did some of the themes and perspectives expressed by Bartram become more widespread among those who traveled in wild natural surroundings or reflected on nature more generally. Even then, in the view of Michael Branch, what was involved was a "minority tradition." 12

In his study of late eighteenth- and early nineteenth-century travel writing, Nigel Leask pointedly refuses to treat all travelers of European origin as fitting into a single, "imperialist" mold and instead insists on the need to fully particularize and contextualize each traveler being analyzed. ${ }^{13}$ I share this approach and will be at pains to apply it, in cultural as well as sociohistorical terms, in the discussion of Bartram that follows.

What, then, went into the making of Bartram's worldview? Elements of it certainly came out of the prevailing intellectual and scientific currents of his time: the attitude of the "curious" Enlightenment savant and natural history collector ${ }^{14}$ and the deism that he imbibed through his father and his father's milieu. But it has been convincingly argued that Bartram's point of view is significantly different from prevalent eighteenth-century concepts of nature, strongly influenced by the reasonings of "natural theology," which attempted to prove the existence of a beneficent god through observation of nature. According to Bruce Silver, while Bartram seems unaware of recent "proto-evolutionary theories of the European Enlightenment" and therefore "[writes] lyrically of nature as God's great product," his approach differs crucially from that of the proponents of natural theology. He does not attempt to prove God's benevolent design through observation-a strategy that often led natural theologians to ignore phenomena that did not fit or to engage in intellectual contortions to make them fit their arguments. Bartram, on the other hand, takes God's omnipresent goodness as a given at the outset and then concentrates on exploring the workings of the natural world without attempting to explain how God's goodness is manifested in every detail. "He wrote about nature as a poet and sometimes thought about it as a philosopher," Silver concludes, "yet his metaphors and morals never overpower the scientific aims of his odyssey." 15

That this was possible points to another cultural and spiritual associationclearly the strongest one that went into his makeup, along with the scientific. This was Quakerism, although not the predominant form that it had come to take in eighteenth-century Philadelphia. Frederick Tolles's now classic study shows how by the middle of that century, the wealthy Quaker merchants in Philadelphia practiced a moderate, mitigated form of their religion — sometimes associated 
with a rationalistic deism — one that was compatible with the pursuit of individual profit and accumulation, thereby distancing themselves to a degree from the original ideals of Quaker faith. ${ }^{16}$ William Bartram grew up in close proximity to this Quaker elite, but he, like John Woolman, was drawn to a more radical Quakerism closer to that of the founders. That faith involved most centrally the value of egalitarianism and affirmation of the oneness, or solidarity, of the human and natural communities. Larry R. Clarke has traced more specifically the aspects of original Quaker beliefs that bear on Bartram's view of nature: knowledge of God is experiential, in an intuitive mode, and does not require rational demonstration; it is "apophatic" in that it eschews making positive, intellectual statements about God; and it can be reached through observing nature. ${ }^{17}$ These aspects of Quaker belief provide a framework for understanding the coexistence in Bartram of an overriding sense of beneficent divinity in nature and close observation of phenomena all of which do not suggest that in and of themselves.

Generally speaking, Bartram drew from the original Quaker spirit a passionate interest in and respect for the natural world, equally in all its parts, and a defense of its integrity - a tradition of Quakerism that has continued to subsist. ${ }^{18}$ Several scholars, including Donald Brooks Kelley and Kerry S. Walters, have more particularly demonstrated how Bartram's approach to nature can be related to that of other figures of the radical subcurrent of Quakerism I have referred to, the so-called weighty or tender Quakers, a group that included Anthony Benezet as well as Woolman. While seventeenth-century American Quakers had shared to an extent Puritan attitudes toward Nature, in the eighteenth century this group developed what Walters calls "a uniquely Quaker ecological sensibility." ${ }^{19}$ Kelley details some key aspects of these Quaker thinkers' credo. They affirmed that God was the only possessor of the earth and man only a custodian or steward of it in a protective relationship that should also extend to animals. Benezet called for a "compact" mode of living similar to that of Indians, and both he and Woolman were critical of the greed for wealth that led to environmental waste. ${ }^{20}$ While the affinities of Bartram with these ideas are quite clear, Walters also emphasizes Bartram's difference - and originality - in relation to them in that his vision was less closely tied to a sectarian Quaker outlook. ${ }^{21}$

Indeed, it has been recognized by most students of his work that there is much in Bartram's vision that goes beyond and stands outside of the Quaker as well as the Enlightenment scientific influences. As Larry Clarke points out, "[his] view of nature as the unspoiled fount and norm of virtue, and of primitive man as more virtuous than civilized, is not part of the Quaker tradition" but is rather "a part of his appeal to the emerging Romantic movement."22 Bartram can in fact be seen as himself possessing an early romantic sensibility if we mean by romanticism - as I have argued elsewhere - a revolt against the conditions of bourgeois modernity and nostalgia for premodern values and life forms. ${ }^{23}$

William Bartram, unlike his father, did not fit in commercial Philadelphia or more generally in the early capitalistic society of the British colonies. William's father had wished him to go into business and set him up as an apprentice to a 


\section{Robert Sayre}

merchant in the late 1750 s and then later, in the 1760s, as a shopkeeper in North Carolina and finally as a commercial rice and indigo planter in Florida. In all of these ventures, William was both unsuccessful and unhappy. When in 1773 he left, alone and against the wishes of his father, on his long expedition in the wilderness of the Southeast, his departure appears to have been in large part an escape from the mercantile destiny to which he had been consigned but for which he had discovered himself totally inept. His departure was in a real sense a retreat from and rejection of his society. He preferred to it "wild" nature and the Indians who lived closely integrated into that environment. ${ }^{24}$

Before turning to Bartram's account of the trip, I will sketch the broad outlines of his philosophical-religious vision. For this passionate Quaker and romantic, at the most general level all the creatures of the world - plants, animals, and humans - are seen to be manifestations of the divine and as such to possess equal value. Profoundly linked, they are part of an overarching unity of life forms, one that human beings should be in touch with and embrace. Yet while all created beings are part of a nonhierarchical whole, in Bartram's understanding this does not mean a leveling down to the lowest common denominator. On the contrary, as Pamela Regis has noted, "[t]he general movement is toward elevation-the plants Bartram mentions are animal-like; the animals are humanlike; the savages are not savage at all." ${ }^{25}$ Only those who are called "civilized" are devalued but only because their mode of life constitutes a negation of vital principles.

Among Bartram's unpublished manuscripts, there are two fragments that very explicitly develop the implications of these convictions, particularly in sociocultural terms. They present in condensed form some of the main themes that ran through the first manuscript version of Travels, much of which was edited out of the final published version. As such, they provide an important philosophical and social background for the travel narrative. ${ }^{26}$

Interestingly, on one of these texts, Bartram also superimposed some drawings, and these can be seen to project significant meanings in a pictorial palimpsest. On the lower part of the page, we see two images: one of a small house that seems to be beside a river and the other of a man walking alone among trees, leaning on a stick. Above these two is a third drawing, of a horse, which seems to be galloping (or possibly jumping since it is oriented upward). All the images involve the natural world, showing fauna and flora and human beings in a natural setting, both living and moving (traveling) within it. The drawing of the man walking in the woods might be a self-portrait of Bartram the "philosophical pilgrim" as he repeatedly called himself in the manuscript version of Travels. ${ }^{27}$

In the texts themselves, Bartram levels a scathing critique at so-called civilized society. In this society-in his own, that is - "the more Any Man or Woman, approaches to Honesty and simplicity, the more he is accounted a Fool and he is in the broad Road, and hastening on to Poverty, contempt and Misery." It is a society in which "the Passion of covetousness is One of the most formidable ... Enimies. This passion if we give way to it becomes insatiable. It is the parant of contention ... and contention begets violence and Warr" (304). The 
pursuit of wealth and the work ethic (or "industry," the term Bartram uses) that accompanies it turn civilized human beings away from the true source of life in nature, leading ultimately to "even a species of suicide. How common is it for Men Whose Aim is for excessive affluance, Riches and fashion able Luxery to ruin their constitution and shorten their Lives, through excessive and constant Labour, fatigue and Watching" (305). For Bartram, then, the mercantile civilization of which he was a part was a system that was unnatural and, as such, deeply damaging from a moral as well as a physical point of view.

The author of these fragments goes on to draw the following conclusions: "Thus it appears I think that we act most rationally and virtuously when our Actions seem to operate from simple instinct [or] apparoach nearest to the maners of the Animal creation." Those nations "who yet remain in the simple state of primitive Nature as our Indians, who had had but little intercourse with White People," are closest to this apparently instinctive life and therefore to true morality (306). The "apparently" is important here since in a number of passages in Travels, Bartram strongly rejects the notion, held by other whites, that the Indians have no developed social institutions but are instinctive "children of nature." For Bartram, they have a structured civilization but one in consonance with and integrated into the rest of the living creation.

As for animals, with which he associates the Indians in the passage, it is clear elsewhere that Bartram means to raise their status rather than to lower that of human beings to a debased animality. In other portions of the fragments, the author ironizes about the self-styled "Dignity of Human Nature," an unmerited distinction since mankind behaves as an "Absolute tyrant" (310) toward other animals and "probably would long ere this have destroyd the whold animal creation if his Arms were not withheld, by the Supreme Creatory \& preserver" (319). Bartram, on the other hand, affirms the "Dignity of Animal Nature" (317) and is convinced that animals express themselves by means of actual languages and demonstrate rational intelligence $(308,319) .{ }^{28}$

In the text of Travels itself, we find many echoes of this overall perspective and concrete illustrations of it, although the broad social criticism has been much toned down, and there are some passages that apparently contradict or attenuate the radical nature of Bartram's vision. These dissonances have led Thomas Hallock to question the coherency of the Bartramian perspective. He calls Travels a "slippery account" that vacillates between different, incompatible positions. ${ }^{29}$ Yet the very discrepancy between the various manuscripts on the one hand - both the fragments discussed above and the early draft of the travel account - and Travels as published on the other would seem to provide an argument against the charge of inconsistency. It seems plausible that the differences between the early manuscript draft and Travels itself can be explained largely by the editing process that led to the published version. This process appears to have resulted in a kind of censorship, one that was probably partially self-imposed and partially exercised by the external editorial hand. In spite of these complicating elements, 


\section{Robert Sayre}

though, the tenor of the whole, even in the modified, final publication, is in my view abundantly clear. I will return to the question of its inconsistencies later.

From the very outset of Travels, the dominant philosophical theme and tone is exhibited. The travel narrative per se is preceded by an introduction. The opening sentence of this preamble signals to the reader the work's focus on "Nature," a focus asserted to be necessary: "The attention of the traveller should be particularly turned, in the first place, to the various works of Nature, to mark the distinctions of the climates he may explore, and to offer such useful observations on the different productions as may occur." ${ }^{30}$ Here the accent is on the useful contribution to knowledge, particularly for the botanist and zoologist, as Bartram goes on to specify.

But the short second paragraph announces the philosophical/religious credo: "This world, as a glorious apartment of the boundless palace of the sovereign Creator, is furnished with an infinite variety of animated scenes, inexpressibly beautiful and pleasing" (15). Several pages further on, we read, "In every order of nature we perceive a variety of qualities distributed amongst individuals, designed for different purposes and uses; yet it appears evident, that the great Author has impartially distributed his favours to his creatures, so that the attributes of each one seem to be of sufficient importance to manifest the divine and inimitable workmanship" (17).

The introduction develops the idea that these qualities and attributes are of the most diverse kinds. The living works of nature, vegetable and animal, impress the observer with their beauty, harmony, awesome mystery, singularity, size, complexity, and so on as well as ingenious usefulness for the organism itself and for others, including man. No individual production of nature will exhibit all or even most of the traits in this eminently subjective list, but each possesses at least one that calls forth wondering admiration. Wonder is indeed one of the dominant notes in Travels, projecting what Josephine Herbst calls Bartram's "enchanted vision of the universe." 31

Beyond this expressed sense of marvel, the introduction, like the work as a whole, points to an ecological awareness of the interconnectedness and unity of living beings. More specifically, Bartram suggests that " $[\mathrm{t}]$ he vital principle or efficient cause of motion and action, in the animal and vegetable system, ... may be more similar than we generally apprehend" (19) and that the "moral system" of animals may not be so different from or inferior to mankind's as is often supposed (21). One of the several anecdotes from his trip recounted in the introduction exemplifies in experiential terms the author's ecological sensitivity. Bartram happens on a large spider stalking its bumblebee prey. The text then carefully describes how the spider deftly carries out its successful attack by taking into account the anticipated behavior of not only the bee but also the human being that is present — not as a disembodied scientific observer but as a part of the natural situation. Bartram concludes the anecdote by putting it in the context of the larger food chain. The spider hid under some leaves to devour the 
bee but, "perhaps before night, became himself the delicious evening repast of a bird or lizard" (25). ${ }^{32}$

Over the course of the following narrative, recurrent passages reinforce and develop the vision announced in the introduction. Early on the journey, while paddling up the Alatamaha River in East Florida, the author rapturously meditates "on the marvellous scenes of primitive nature, as yet unmodified by the hand of man" (65). Some months later, on another river in Florida — the St. John's-Bartram reflects that, in contrast with a temporary traveling companion who seemed only to want to establish himself in a trade and prosper, his own "chief happiness consisted in tracing and admiring the infinite power, majesty, and perfection of the great Almighty Creator" (82), adding, but as if in an afterthought, that it came also from the expectation of providing useful knowledge. Later still, when he has reached the upper reaches of the St. John's, in a very remote area inhabited only by Seminole Indians and the few traders who deal with them, Bartram has an experience of paradisiacal plenitude. Camping with a companion, he feels supremely happy and, echoing an ancient trope of Western culture, associates his state with that of a primitive, golden age. Recalling one night spent by the campfire, the author exclaims,

How supremely blessed were our hours at this time! plenty of delicious and healthful food ... with contented minds; under no controul, but what reason and ordinate passions dictated, far removed from the seats of strife. Our situation was like that of the primitive state of man, peaceable, contented and sociable. The simple and necessary calls of nature being satisfied, we were altogether as brethren of one family, strangers to envy, malice, and rapine. (109-10)

In this passage, Bartram communes with another human being in the midst of Nature. But in some others, he feels a similar closeness to animals, as in one occurring much later in his travels in which he "advanced into the strawberry plains to regale on the fragrant, delicious fruit, welcomed by communities of the splendid meleagris, the capricious roe-buck, and all the free and happy tribes, which possess and inhabit those prolific fields, who appeared to invite, and joined with me in the participation of the bountiful repast presented to us from the lap of nature" (282). Here Bartram is in Cherokee territory, and a few pages later his account provides another ecstatic description of strawberry fields, this time shared not with deer and other wildlife but with a host of Indian girls (288-90). The account of his and his fellow traveler's encounter with the girls, who are gathering and eating berries and bathing, is sensuous and erotic without being explicitly lewd and depends for its effect on the lush natural landscape in which it is set. A note of coy humor at the end points to the men's attraction itself being part of "nature." When, "nature prevailing over reason, we wished at least to have 


\section{Robert Sayre}

a more active part in their delicious sports," a group of older women appeared and "gave the alarm" (289). The story ends with the sharing of strawberries by all.

As he moves in and out of wilderness areas and through intermediary zones that have to some extent been changed by European presence, Bartram often explicitly states his preference for wild sites as opposed to those that have been "improved" by settlers. This is the case, for example, when he tells of a time at which he found himself "about sixty miles south of the Alatamaha, passing through an uninhabited wilderness. The sudden transition from rich cultivated settlements, to high pine forests, dark and grassy savannas, forms in my opinion no disagreeable contrasts; and the new objects of observation in the works of nature soon reconcile the surprised imagination to the change" (42). The insistence by the author that this is his opinion seems to indicate that he is contradicting a common, contrary reaction. As has been pointed out by many commentators, Bartram's descriptions of the wilds often draw on the "sublime," a literary form then beginning to come to the fore that celebrates the intensity of unbridled and extreme natural phenomena. ${ }^{33}$ But clearly the reader of Travels was expected to be likely to respond with the more traditional preference for cultivated, "improved" land.

Another context in which the contrast between land touched or untouched by settlement can become tangible is when Bartram revisits a spot that has undergone a transformation since his previous visit. On the banks of Lake George, for example, at the head of the St. John's River, Bartram recalled that "[a]bout fifteen years ago I visited this place, at which time there were no settlements of white people, but all appeared wild and savage; yet in that uncultivated state it possessed an almost inexpressible air of grandeur, which was now entirely changed" (101). Since the earlier visit, it had been cleared, planted with crops, and then abandoned so that it now was unattractive and desertous (102). ${ }^{34}$

Overwhelmingly, then, Bartram celebrates the wild nature that he travels through and stops in, preferring it to lands settled by Europeans. This point of view, however, is not entirely unadulterated in Travels. On several occasions when near the coast and still in the English zone of habitation, Bartram expresses considerable admiration for the "improvements" made on the estates of some of the commercial planters he stays with en route to outlying territories $(37,77,85)$. $\mathrm{He}$ at the same time regularly praises the characters of the planters themselves.

Moreover, in several places, Bartram uses a kind of rhetorical figure that is common in other British American travel accounts, one such I alluded to in John Lawson's narrative. The traveler, in a wild landscape still under Indian control, conjures up in his mind's eye - and in the text — what the land could become if under British control and ownership. The implication is that the change would be desirable, and the function of the passage is also to provide exploitable information for those interested in participating in colonizing ventures. One such instance occurs when Bartram is recounting his passage through Creek and Choctaw country. He comments at one point that " $[\mathrm{t}]$ he territory lying upon this creek, and the space between it and the river, present every appearance of a delightful 
and fruitful region in some future day, it being a rich soil, and exceedingly well situated for every branch of agriculture and grazing," adding that waterways from it would allow "uninterrupted navigation to the bay of Mexico and the Atlantic Ocean" (309).

Yet these passages are limited in number, and one of them is revealing because in it Bartram seems to betray his true viewpoint in spite of himself: "This vast plain, together with the forests contiguous to it, if permitted (by the Siminoles who are sovereigns of these realms) to be in possession and under the culture of industrious planters and mechanics, would in a little time exhibit other scenes than it does at present, delightful as it is; for by the arts of agriculture and commerce, almost every desirable thing in life might be produced and made plentiful here" (199). Two things distinguish this passage from usual formulations in other travel accounts. First, the Seminoles are designated as the "sovereigns" who would have to freely cede their lands if the change were to take place. Second, the phrase "delightful as it is" reveals the underlying regret felt by the author at the thought that the natural beauty of the spot, maintained by the Indians, could disappear. In other passages, in fact, Bartram severely criticizes settlers for the destruction of natural beauties (e.g., 213).

It would seem, then, as I have already suggested, that the dissonant passages, limited as they are, can be laid down either to editorial intervention or to the more subtle pressure exercised by strong prevailing norms on a sensibility that was atypical and marginal to the extreme. The difference in this respect between the early manuscript version and the published work would tend to corroborate the contention that these passages do not correspond to Bartram's deepest sensibilities. As Thomas Hallock himself has noted, "[t]he genetic text shows little interest in expansion ... and portrays nature as a source of inspiration rather than as a commodity." ${ }^{35}$ The same can be said of Bartram's being generally well disposed toward the planters near the coast in Travels. Christopher Iannini, another commentator who has laid emphasis on Bartram's implication in British colonialism, acknowledges that the figure of the "benevolent planter" does not appear in any known manuscript versions. ${ }^{36}$

Beyond that, Bartram is crucially far more critical of the behavior of whites in the wilderness. Those whom he encountered were settlers, surveyors, and traders but most often the latter. Although he often traveled alone and almost always reveled in this mode of travel, he was in many cases obliged - especially due to tensions between Indians and whites - to join caravans, constituted largely of traders, in traversing long stretches of unsettled land. Although he did befriend some traders - particularly among the older and more experienced, whose sagacity he occasionally praises - they were exceptional cases, as he points out himself.

When traveling with traders, Bartram most often chose to stay apart from them on the trail, preferring the society of plants and animals to theirs. Recounting one such expedition with a company of traders crossing some of his most beloved terrain in Florida, Bartram notes that "[h]aving a good spirited horse under me, I generally kept a-head of my companions, which I often chose to do, 


\section{Robert Sayre}

as circumstances offered and invited, for the sake of retirement and observation" (187). The mode of travel of these white men is entirely different from that of Indians, and Bartram is highly critical of their practices. They break camp late in the morning and stop their trek already in mid-afternoon. But what outrages Bartram most, as he comments in relation to another, later excursion in Choctaw country farther west, is that they press their horses mercilessly with loud cries and curses - accompanied by continual whipping - filling the air with "an incessant uproar and confusion, inexpressibly disagreeble" (351). Such a manner of traveling exhibits the traders' insensitivity to the suffering of animals (Bartram was particularly distressed, on the excursion in Choctaw territory, by that of his own horse, which became seriously exhausted by the caravan's "infernal" pace) and at the same time their total indifference to the natural scenes they pass through.

The cruelty of white travelers in the wilderness extends to wild animals as well. Bartram tells of one incident in which he and his traveling companions were approached by an alligator at night. The person who had discovered it was quickly joined by all the others in the party, "for it was a rare piece of sport." They attacked the alligator with firebrands and rammed javelins down his throat. While a few were in favor of "putting an end to his life and sufferings with a rifle ball, ... the majority thought this would too soon deprive them of the diversion and pleasure of exercising their various inventions of torture" (210). Only when they grew tired of the game did they put the animal out of its misery. Bartram reports a similar occurrence at a much later date when another company of traders spied a litter of wolf cubs, chased them, and captured one of them: "one of our people caught it by the hind legs, and another beat out its brains with the but [sic] of his gun,-—barbarous sport!" (319).

This seemingly widespread indifference to the suffering of animals is often accompanied by a lack of concern with wasting natural resources. Bartram becomes indignant at one point when his fellow travelers kill and cook a tortoise of which they know they will not be able to eat more than half: "my companions, however, seemed regardless, being in the midst of plenty and variety, at any time within our reach, and to be obtained with little or no trouble or fatigue on our part" (159). Even one of the elder traders, one with whom Bartram was on friendly terms, seemed to share this attitude. When a party that the two of them were traveling with sited a herd of deer, "I endeavoured to plead for their lives; but my old friend, though he was a sensible rational and good sort of man, would not yield to my philosophy" (174). These examples strikingly highlight the exceptional nature of Bartram's awareness of ecological issues in the eighteenthcentury North American context of seemingly infinite natural abundance.

In contrast to the behavior of the whites stands that of the Indians, whom Bartram perceives to be at home in their natural habitats, which they treat in ways that seem to maintain rather than destroy them. These habitats constitute a kind of utopian home for Bartram himself, who is maladapted to and in flight from the British American mentality and world. Here, for example, is Bartram's comment on a scene he came on in East Florida: 
I penetrated the grove, and afterwards entered some almost unlimited savannas and plains, which were absolutely enchanting; they had been lately burnt by the Indian hunters, and had just now recovered their vernal verdure and gaiety. How happily situated is this retired spot of earth! What an elysium it is! where the wandering Siminole, the naked red warrior, roams at large, and after the vigorous chase retires from the scorching heat of the meridian sun. ... Seduced by these ... visions of terrestrial happiness, ... I had roved far away ... . I turned about, and in the evening regained our camp. (107)

In this passage, Bartram displays both an understanding of the way the Indians played an active role in modifying (without dilapidating) the natural environment and a lyrical sense of their being the inhabitants of Nature's utopia. ${ }^{37}$

As reported by Bartram, the Indians he came to know often reciprocally recognized in him a kindred spirit, an exception among Europeans, one who had no desire to appropriate their lands. One Seminole chief gave him "unlimited permission to travel over the country for the purpose of collecting flowers, medicinal plants, \&c. saluting me by the name of Puc Puggy, or the Flower hunter, recommending me to the friendship and protection of his people" (163). Another said that "I was as one of his own children or people, and should be protected accordingly" (201). In Travels, then, Bartram presents himself as one who found his true home in an unspoiled natural environment, as the adoptive son of its Native American guardians.

In the numerous drawings that he produced for his patron John Fothergill during the 1773-1777 trip - a few of which were reproduced in Travels - as well as in those he did earlier and later, one finds many aspects of Bartram's idiosyncratic perspective translated into visual terms ${ }^{38}$ Although intended for scientific purposes, they often project Bartram's own way of interpreting and responding to the natural world. As Thomas Hallock has brought out in his study of Bartram's artwork, they combine the mimetic, the aesthetic, and the emotive in a manner that evokes tremendous vitality. ${ }^{39}$ Although it is not possible within the framework of this article to undertake a thorough analysis of the drawings, a few general remarks are in order as a complement to the preceding discussion of Bartram's written works. ${ }^{40}$

One of the key aspects of Bartram's ecological vision - a sense of unity and interconnectedness in the world of living beings - is strongly conveyed in many of the drawings. At the simplest level and closest to the taxonomic purposes of many of the works, representations of single plants often display the different stages of the organism's life cycle. But beyond this, a large number of images include not one but several life forms, both vegetable and animal, often mixing the two. In one drawing, for example, we are shown a plant, a bird, a crab, and a seashell and in another several plants, a bird, and a fish. In some cases, the organisms are simply juxtaposed, but in others, they are shown in interaction. 

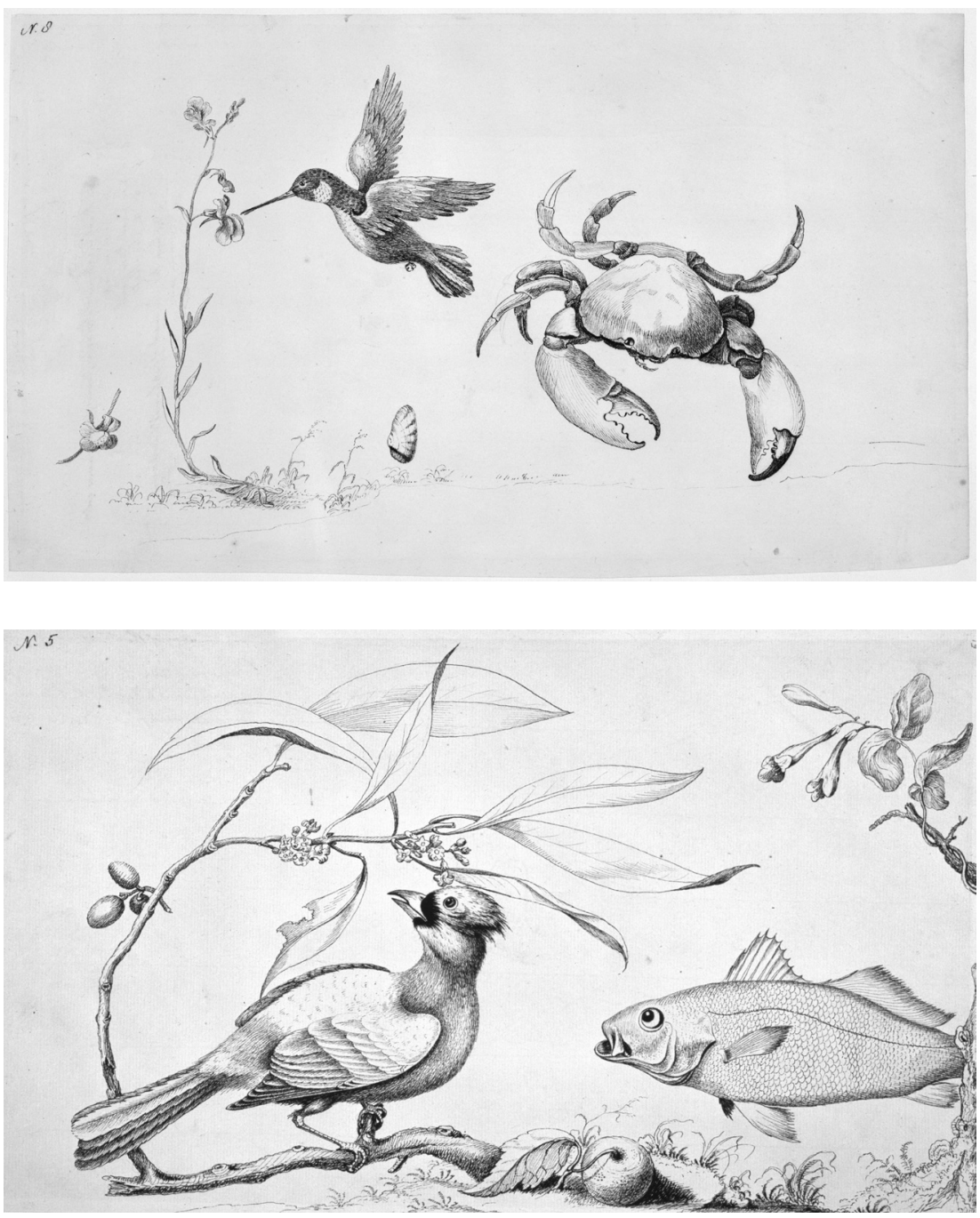

With animals, the most common type of interaction is ingestion. One is pictured in the process of devouring another, as in the textual description of the spider and the bumblebee alluded to earlier. In several drawings, we are witness to a snake eating a frog, while in another, a larger snake has almost finished swallowing a smaller one. In other images, the animal is only looking at its prey but with clear intent. In one case, a bird on a branch looks at a flying insect, and in another, a waterbird directs its beak toward a small crustacean on a beach.

While some of Bartram's representations of life forms are set against a neutral, featureless background, in many of them a further element of interrelatedness is introduced by the depiction of the typical environments of the organisms under display. Thus, to give just one example, in the drawing already alluded to of one 
William Bartram and Environmentalism 81
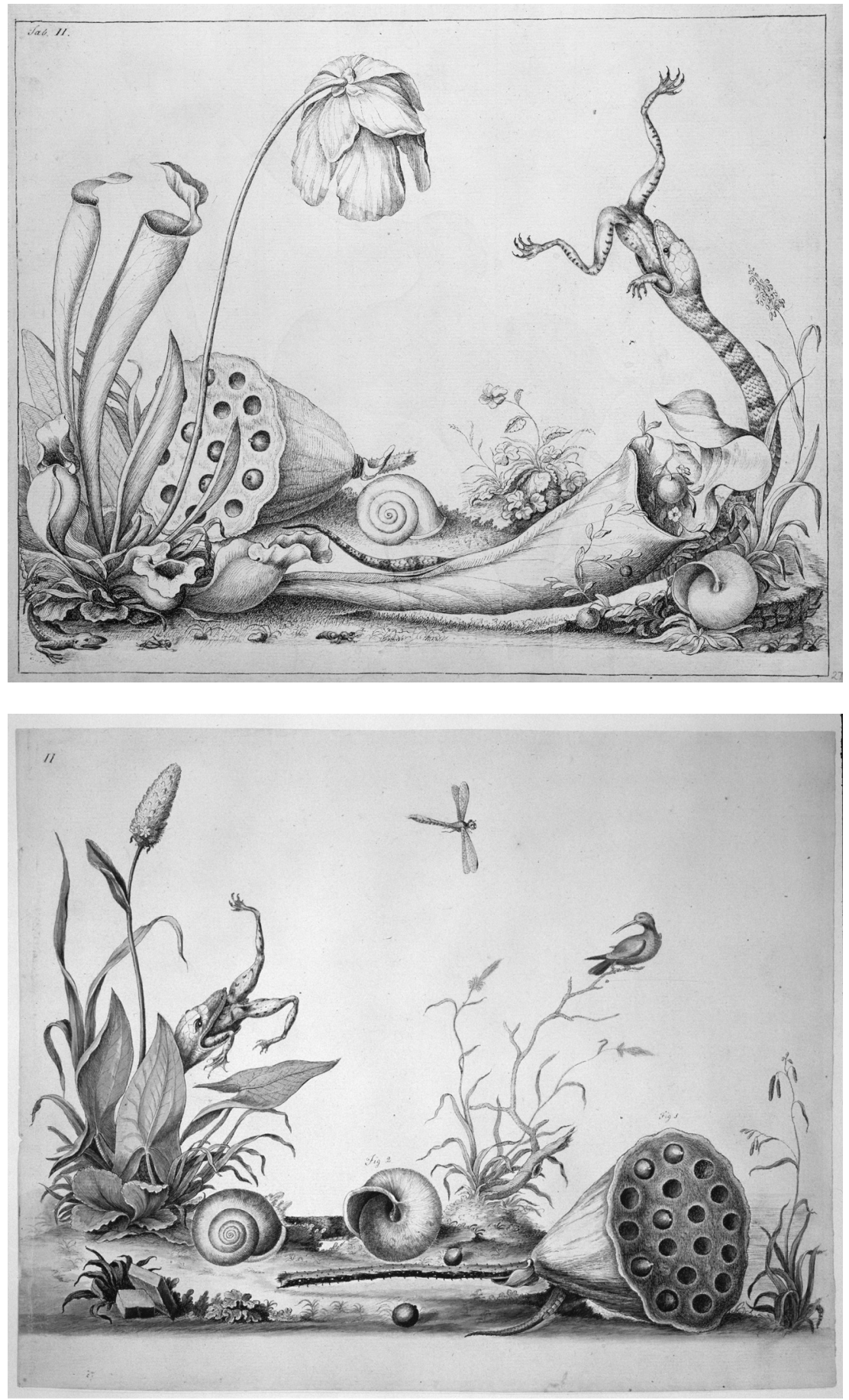


\section{Robert Sayre}

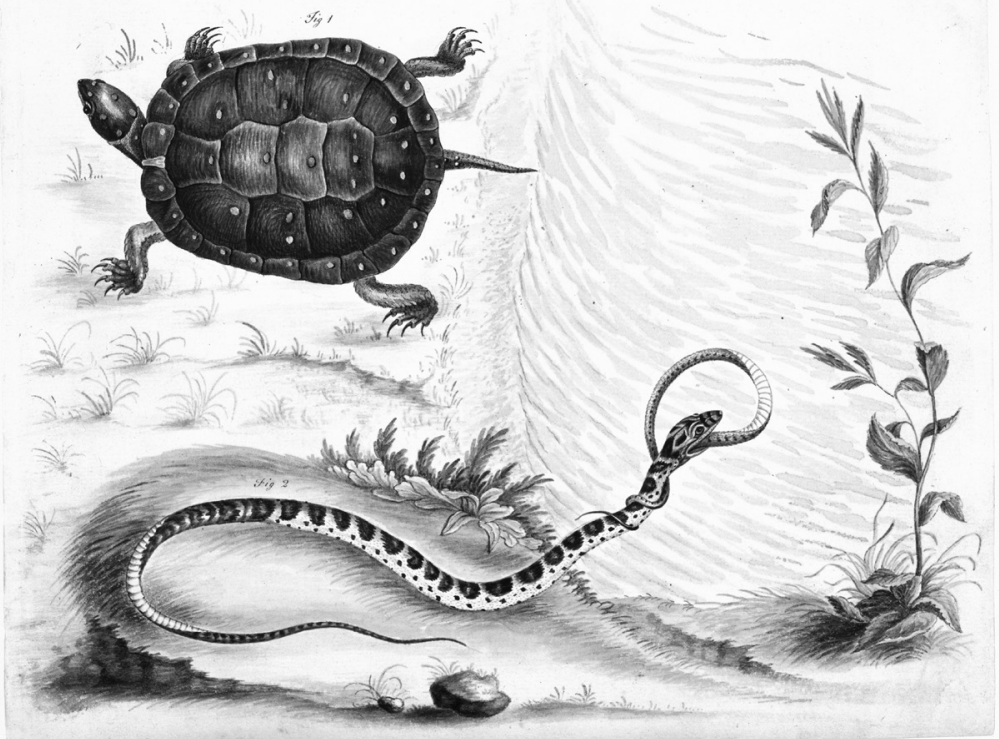

57

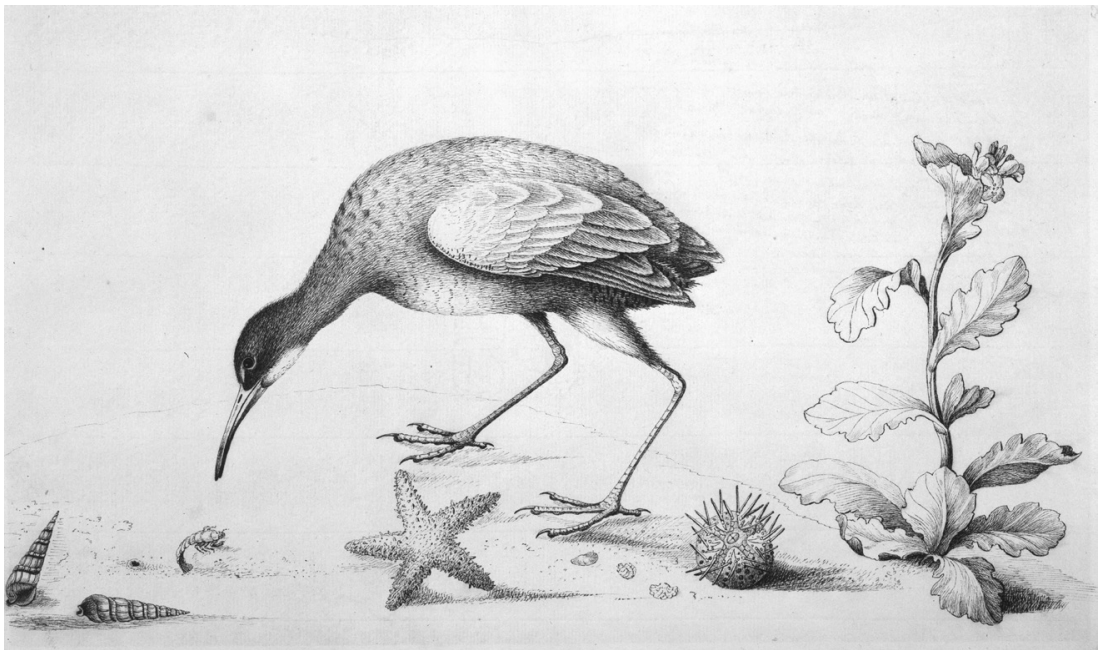

snake eating another, the snakes are pictured on the edge of a body of water; in the water is an aquatic plant and onshore some tufted ground cover and a tortoise. To the various principles of unity at work in Bartram's drawings, which include morphological analogy, life cycle, and food chain, can be added that of habitat.

Although most of the drawings are of nonhuman subjects, in one a stone calumet head appears alongside a plant, a snail, and a crawling insect, establishing 


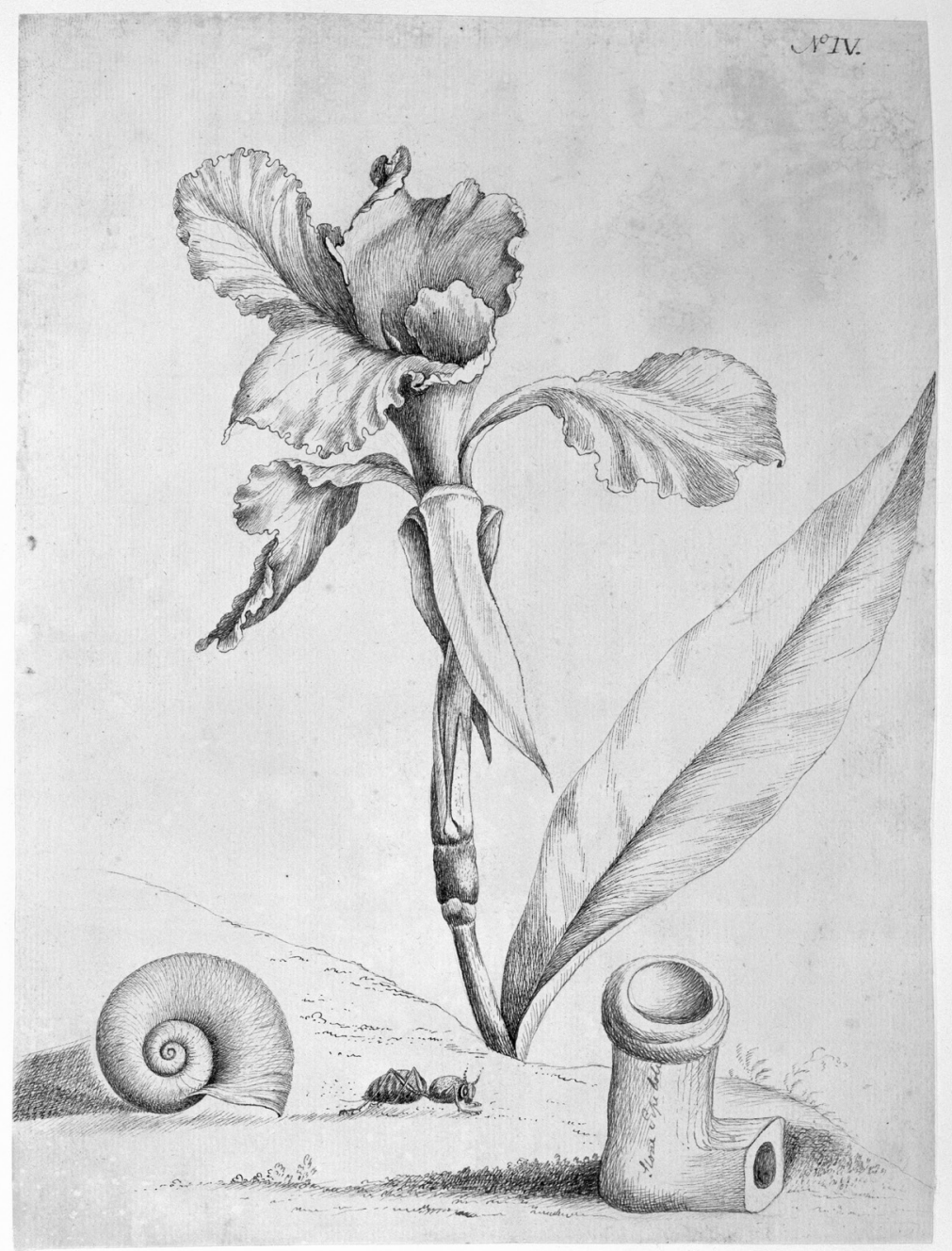

a connection with Indian culture. ${ }^{41}$ But more broadly, a bridge between human and nonhuman life is suggested by what has struck many observers as the anthropomorphic expressiveness of many of Bartram's plants and animals. Thomas Hallock cites approvingly, in fact, one of his students who felt that they seem to "have personalities." ${ }^{42}$ In this way, as well as through the aesthetic beauty-of line and sometimes of color-in his imaging of them, Bartram expresses his immense attraction to and even identification with the denizens of the natural world.

In recent times, the approach that critically analyzes texts in light of the politics of colonial control and domination has often been applied to natural history 


\section{Robert Sayre}

and nature writing. Mary-Louise Pratt, whose Imperial Eyes has been a seminal work for this school of thought, ${ }^{43}$ coined the term "anti-conquest" to describe the role played by the early natural science travelers. From this viewpoint, as Christoph Irmscher has summarized it, "naturalists were the willing, if slightly befuddled, accomplices of Western imperialism" 44 since their Enlightenment project of imposing and extending rational understanding and classification of Nature went hand in hand with the imperial and colonial onslaught. Some analysts of the work of William Bartram have included him within this estimation. James Cox, author of a study of travel literature in the American South, points out that one trend in critical discussion of Bartram and his Travels has claimed that "his exploitive tendencies outweigh his 'environmentalist' sensibilities." ${ }^{\text {"45 }}$ In what has preceded, I hope to have shown the contrary and, moreover, that Bartram's true nature is the very opposite of exploitive.

In this article, I have attempted to demonstrate that Bartram's work represents an early, significant contribution to the development of environmentalism in several respects: in his protoecological awareness of biosystems, in his shift of perspective from "anthropocentrism" to "ecocentrism," in his valuing of "wild" nature outside the control of human beings, and in his desire to protect nature from human depredation. I have also endeavored to show that Bartram's environmental vision is closely related to his alienation from and critique of the commercial, colonialist society into which he was born. I have argued that, in spite of apparent ambiguities and contradictions, Bartram's worldview, in both its ecological and its social aspects, is radical at its heart.

Many contextual factors can be brought to bear to explain the ways in which Bartram's works sometimes deviate from that core. In eighteenth-century British America - and a fortiori in Philadelphia, one of its primary urban centers - the pressure of the dominant ideology - utilitarian, expansionist, and technologically manipulative - was intense. In this context, which was also that of a highly volatile, transitional period, many or perhaps even most intellectual productions were rife with unresolved tensions. Hence, it is not surprising that - through the editorial process, both internal and external, as I have suggested-Bartram's published work came to manifest some such fault lines. His temperament, which seemingly was tender and eschewed conflict, also probably played a role, predisposing him to seek reconciliation of positions. In reading Travels, one does sometimes sense, as Thomas Hallock maintains, a "desire to evade" - to evade confrontation with intractable, unpleasant realities ${ }^{46}$ This is by no means always the case, however. And, most important, Bartram's occasional hesitancies should not obscure the radical nature and power of his essential vision.

\section{Notes}

1. Aaron Sachs, The Humboldt Current: Nineteenth-Century Exploration and the Roots of American Environmentalism (New York: Viking, 2006), 2.

2. See notably Lawrence Buell, The Environmental Imagination: Thoreau, Nature Writing and the Formation of American Culture (Cambridge, MA: Harvard University Press, 1995), 62, 77, 81, and Michael Branch, "Indexing American Possibilities: The Natural History Writing of Bartram, 
Wilson, and Audubon," in The Ecocriticism Reader: Landmarks in Literary Ecology, ed. Cheryll Glotfelty and Harold Fromm (Athens: University of Georgia Press, 1996), 288, 89. Branch is the editor of Reading the Roots: Nature Writing before Walden (Athens: University of Georgia Press, 2004). In addition to scholarly interest connected with modern environmentalism, Bartram has come to be known and fervently admired by a wide public. The two organizations devoted to William Bartram today - the Bartram Trail Conference and the North Carolina Bartram Trail Society-have well-appointed websites publicizing their activities. These include regular meetings and symposia and publications of various kinds, but the main focus is on visiting Bartram locales and following and maintaining Bartram routes of travel.

3. The full title of the work is Travels through North and South Carolina, Georgia, East and West Florida, the Cherokee Country, the Extensive Territories of the Muscogulges or Creek Confederacy, and the Country of the Chactaws.

4. The manuscript was first published as "Travels in Georgia and Florida, 1773-74: A Report to Dr. John Fothergill," in Transactions of the American Philosophical Society, new series, 33, November 1943, ed. Francis Harper. More recently, it has been republished in William Bartram, Travels and Other Writings, ed. Thomas P. Slaughter (New York: The Library of America, 1996).

5. This text has been transcribed and carefully studied in Nancy E. Hoffmann's doctoral dissertation "The Construction of William Bartram's Narrative Natural History: A Genetic Text of the Draft Manuscript for Travels through North and South Carolina, Georgia, East and West Florida" (PhD diss., University of Pennsylvania, 1996).

6. See Rose Marie Cutting, John and William Bartram, William Byrd II and St. John de Crèvecoeur: A Reference Guide (Boston: G. K. Hall, 1976), x, 37, 68.

7. See Henry David Thoreau, $A$ Week on the Concord and Merrimack Rivers; Walden, or Life in the Woods; The Maine Woods; Cape Cod (New York: Viking Press, 1985), 376-77, and Ralph Waldo Emerson, Selected Journals 1820-1842 (New York: Penguin, 2010), 487. On the influences of Bartram's Travels on both European and American nineteenth-century writers, see Cutting, John and William Bartram, 45, 57, and N. Bryllion Fagin, William Bartram: Interpreter of the American Landscape (Baltimore: Johns Hopkins University Press, 1933), 128-200. Fagin mentions, in addition to Thoreau and Emerson, Poe's friend and supporter Thomas Holley Chivers as another American admirer of Bartram. See also Thomas P. Slaughter, The Natures of John and William Bartram (New York: Vintage, 1997), xvi, 163, 248, 257. Slaughter sees a particularly strong affinity between William Bartram and Thoreau, calling the latter an "heir" to the former's "naturalistic legacy" (248). In their introduction to William Bartram, The Search for Nature's Design: Selected Art, Letters, and Unpublished Writings, ed. Thomas Hallock and Nancy E. Hoffmann (Athens: University of Georgia Press, 2010), Hallock and Hoffmann speak of Bartram having "inspired . . . an entire tradition of nature writing in America" (2).

8. Annette Kolodny, "Unearthing Herstory: An Introduction," in Glotfelty and Fromm, The Ecocriticism Reader, 175.

9. See John Lawson, A New Voyage to Carolina, ed. Hugh Talmage Lefler (Chapel Hill: University of North Carolina Press, 1967). Lawson also collected botanical specimens for a European patron, however, and his work contains elements of natural history as well.

10. For a modern edition of the work that follows the first edition of London, 1801, see Alexander Mackenzie, Voyages from Montreal on the River St. Laurence through the Continent of North America to the Frozen and Pacific Oceans in the Years 1789 and 1793, with a Preliminary Account of the Rise, Progress, and Present State of the Fur Trade of That Country (Toronto: The Radisson Society of Canada, 1927). For an analysis of Mackenzie's account, see Robert Sayre, "Alexander Mackenzie's Search for the Northwest Passage: The Commercial Imperative (1789-93)," in The Quest for the Northwest Passage: Knowledge, Nation and Empire, 1576-1806, ed. F. Regard (London: Pickering \& Chatto, 2013), 121-37.

11. Roderick Nash, Wilderness and the American Mind (1967; 3rd ed., New Haven, CT: Yale University Press, 1982), 53, 55.

12. Branch, "Indexing American Possibilities," 286.

13. See Nigel Leask, Curiosity and the Aesthetics of Travel Writing, 1770-1840 (Oxford: Oxford University Press, 2002), introduction.

14. Pamela Regis, who emphasizes the scientific side of Bartram, takes her cue from a passage in Travels to identify "curiosity" as his "attendant spirit" in Describing Early America: Bartram, Jefferson, Crèvecoeur, and the Rhetoric of Natural History (Dekalb: Northern Illinois University Press, 1992), 64.

15. Bruce Silver, "William Bartram's and Other Eighteenth-Century Accounts of Nature," Journal of the History of Ideas 39 (1978): 600, 614.

16.'See Frederick Tolles, Meeting House and Counting House: The Quaker Merchants of Colonial Philadelphia, 1682-1763 (New York: Norton, 1948).

17. Larry R. Clarke, "The Quaker Background of William Bartram's View of Nature," Journal of the History of Ideas 46, no. 3 (1985): 435-48. In a critical commentary on this article, Bruce Silver argues that the ideas Clarke attributes to Quakerism are not specific to it. In making this claim, however, Silver remains at a relatively high level of generality and does not address all of the particulars 


\section{Robert Sayre}

adduced by Clarke; see Silver, "Clarke on the Quaker Background of William Bartram's Approach to Nature," Journal of the History of Ideas 47, no. 3 (July-September 1986): 507-10.

18. See David Sox, Quaker Plant Hunters: From North America's Early Frontier to the South Pacific (York: Sessions Book Trust, 2004), introduction.

19. Kerry S. Walters, "The 'Peaceable Disposition' of Animals: William Bartram on the Moral Sensibility of Brute Creation," Pennsylvania History 56, no. 3 (July 1989): 162. John Gatta uses the term "ecospirituality" with reference to the Quaker ecology of Woolman and Bartram in Making Nature Sacred: Literature, Religion and the Environment in America from the Puritans to the Present (Oxford: Oxford University Press, 2004), chap. 2, "Meditating on the Creatures in Early American Life and Letters."

20. See Donald Brooks Kelley, "The Evolution of Quaker Theology and the Unfolding of a Distinctive Quaker Ecological Perspective in Eighteenth-Century America," Pennsylvania History 52 (October 1985) : 244, 248-49, and "Friends and Nature in America: Toward an Eighteenth-Century Quaker Ecology," Pennsylvania History 53 (October 1986): 261-66.

21. Walters, "The 'Peaceable Disposition of Animals,"” 159-60, 162, 165, 167. Walters stresses the influence of Quietism on the eighteenth-century movement of thought and in another article argues that Bartram's ideas reflect Christian neoplatonism via the Quakers; see Walters, "The Creator's Boundless Palace: William Bartram's Philosophy of Nature," Transactions of the Charles S. Peirce Society 25, no. 3 (Summer 1989): 309-32.

22. Clarke, "The Quaker Background," 446.

23. [citation removed to keep article blind]

24. On Bartram's life, with emphasis on his relations with his father, see Slaughter, The Natures of John and William Bartram. For cogent reflections on his life, see also William Bartram on the Southeastern Indians, ed. and annot. Gregory A. Waselkov and Kathryn E. Holland Braund (Lincoln: University of Nebraska Press, 1995), chap. 1.

25. Regis, Describing Early America, 48.

26. "Thoughts on Morality," manuscript fragments without dates: Pennsylvania Historical Society, Bartram Papers, vol. 1, folders 81,83 . The texts of these documents have been transcribed in Hoffmann, "The Construction of William Bartram's Narrative Natural History," app. C. The page numbers cited for my quotations will refer to this transcription and will be noted parenthetically in the text.

27. These images have not been mentioned, to my knowledge, in any other discussions of these manuscripts.

28. For further discussion of Bartram's views on animals, see Walters, "The 'Peaceable Disposition' of Animals."

29. Thomas Hallock, “'On the Borders of a New World': Ecology, Frontier Plots, and Imperial Elegy in William Bartram's Travels," South Atlantic Review 66, no. 4 (Autumn 2001): 125; see also $112,120$.

30. William Bartram, Travels (New York: Penguin, 1988), 15. Further references will be made to this edition and will be given parenthtically in the text.

31. Josephine Herbst, New Green World (New York: Hastings House, 1954), 119.

32. This is one of the passages often singled out as illustrative of Bartram's ecologically minded elaborations. Another, involving the tiny, short-lived "ephemerae" that inhabit swampy areas, is the example chosen by Chris Magoc for his selection of environmentalist texts because it "captures the essence of ecological thought in its embrionic period"; see Magoc, So Glorious a Landscape: Nature and the Environment in American History and Culture, with documents and readings (Wilmington, DE: Scholarly Resources, 2002), 107.

33. Stephanie Volmer points to the wide diversity of styles in Travels, including notably the "sublime" and the "picturesque," in "William Bartram and the Forms of Natural History," in Fields of Vision: Essays on the Travels of William Bartram, ed. Kathryn E. Holland Braund and Charlotte M. Porter (Tuscaloosa: University of Alabama Press, 2010), 78.

34. In his recent study of the St. John's River in the eighteenth century and its treatment by Bartram, Daniel Schafer has suggested that the latter often chose not to mention plantations that existed at the time of his 1773-1777 travels, thereby "creat[ing] an idealized world of pristine nature ... and based that vision on his observations of the river valley during the mid-1760s"; see Schafer, William Bartram and the Ghost Plantations of British East Florida (Gainesville: University Press of Florida, 2010), 6. As the above-quoted passage evidences, however, the author did in some cases refer to changes that had occurred between the two trips. More generally, as Kathryn Braund points out, in Travels Bartram continually refers to transformations of the land both by European settlers and by Native Americans; see Braund, "The Real Worlds of William Bartram's Travels," in Bartram 's Living Legacy: The Travels and the Nature of the South, ed. Dorinda G. Dallmeyer (Macon, GA: Mercer University Press, 2010), 439.

35. Hallock, "'On the Borders of a New World," 112.

36. Christopher P. Iannini, Fatal Revolutions: Natural History, West Indian Slavery, and the Routes of American Literature (Chapel Hill: University of North Carolina Press, for the Omohundro Institute of Early American History and Culture, 2012), 199. 
37. Since the 1990s, a number of scholarly books and articles have questioned the stereotype of the "ecological Indian." While they have been beneficial in combating oversimplifications and providing a welcome corrective to the notion that Indians were passive "children of nature" who never actively molded their environments to their purposes, many of the claims made and arguments developed remain speculative and controversial. Many of the issues they have raised are the subject of ongoing debate, and they have not provided any conclusive demonstration that Indian pratices, at least before the presence of Europeans began to influence their behavior, produced significantly harmful or self-defeating effects on their environment. For a recent publication that synthesizes past discussions and contributes to the current debate, see Michael E. Harkin and David Rich Lewis, eds., Native Americans and the Environment: Perspectives on the Ecological Indian(Lincoln: University of Nebraska Press, 2007).

38. Reproductions from the important Fothergill collection, housed in the British Museum, are to be found in Joseph Ewan, ed., William Bartram: Botanical and Zoological Drawings, 1756-1788 (Philadelphia: American Philosophical Society, 1968). A generous selection of drawings and watercolors covering Bartram's entire career is included in Bartram, Travels and Other Writings.

39. See Thomas Hallock, "Vivification and the Early Art of William Bartram," in A Keener Perception: Ecocritical Studies in American Art History, ed. Alan C. Braddock and Christoph Irmscher (Tuscaloosa: University of Alabama Press, 2009), 43-60.

40. For extended discussions of Bartram's drawings, including their relation to those of other naturalist-illustrators, such as Mark Catesby and Audubon, see Amy R. Weinstein Meyers, "Sketches from the Wilderness: Changing Conceptions of Nature in American Natural History Illustration: 1680-1880" (PhD diss., Yale University, 1985), chaps. 3, 4, and her much later book Knowing Nature: Art and Science in Philadelphia, 1740-1840 (New Haven, CT: Yale University Press, 2011), $137-53$

41. This juxtaposition of an Indian artifact with animal and plant organisms might be interpreted by some as indicative of a naturalization of Native Americans by Bartram, but it should be clear from the previous discussion that such was not the case. Bartram held Indians to be fully "civilized" human beings, but participants in a civilization far more closely integrated within the natural world than that of the European colonizers.

42. Hallock, "Vivification and the Early Art of William Bartram," 53. 1992).

43. Mary-Louise Pratt, Imperial Eyes: Travel Writing and Transculturation (London: Routledge,

44. Christoph Irmscher, The Poetics of Natural History: From John Bartram to William James (New Brunswick, NJ: Rutgers University Press, 1999), 6.

45. John D. Cox, Traveling South: Travel Narratives and the Construction of American Identity (Athens: University of Georgia Press, 2005), 44.

46. Hallock, "'On the Borders of a New World,"” 130. 
